\title{
CREATING LOVEMARKS THROUGH STUDENTS OF PUBLIC UNIVERSITIES IN IRELAND
}

\author{
Javier Casanoves-Boix ${ }^{1}$, Ana Cruz-García ${ }^{2}, \&$ Maurice Murphy ${ }^{2}$ \\ ${ }^{1}$ Department of Marketing, Valencian International University / Valencia (Spain) \\ ${ }^{2}$ Department of Marketing, Munster Technological University / Cork (Ireland)
}

\begin{abstract}
This research was carried out to examine the role of educational brand capital applied to public universities in Ireland. To this end, the main contributions in the literature related to the study of brand capital and its application in the Irish educational sector were analyzed, identifying which variables determine brand capital in this sector. Once a suitable model was established, an empirical study was realized using a sample of 423 valid responses from students at the two main public universities in Cork (Ireland). The results obtained will show the repercussion of each variable of the brand capital relative to the determining variables (brand awareness, brand image, perceived quality, and brand loyalty), while laying the foundation for university managers to develop marketing strategies adapted to maximize the building of educational brand capital.
\end{abstract}

Keywords: Marketing, brand capital, higher education, public universities, Ireland.

\section{Introduction}

The number of organizations with an affinity to generate efforts towards brand creation is increasing, which is considered one of the most important assets (Kaynak, Salman, and Tatoglu, 2008). Thus, it is essential to study those attitudes of consumers that can favour (or disadvantage) their relationship with the brand (Batra, Ahuvia, and Bagozzi, 2012). In recent years, and due to the high demand that consumers have acquired in their purchase decision-making, the experience of use and consumption is a key piece to detect the perceptions of customers with the brand and, at the same time, maximize their loyalty to it (Henao and Colorado, 2017).

At the university level, since the twentieth century, the pressure to conform teaching and research to the economic, technical, and administrative demands of the moment have been emphasized, seeking to design appropriate solutions to satisfy an increasingly demanding market (Morín, 2018). Thus, today's universities develop their activity in a highly competitive and complex environment, seeking to increase the offer of studies in the region in which they operate and even overcome it through the international offer thanks to the virtual modality (García and Pelekais, 2012). In that sense, Manes (2008) considers that it is necessary for every university to incorporate a marketing area in its process, seeking to maximize business opportunities. Thus, and according to Durán and Parra (2014), the university marketing strategy, whether in the public or private sphere, is considered key to improving the service offered in an increasingly demanding client, while helping to create diversity and compete in increasingly heterogeneous markets.

Focusing our attention on the role that public higher education plays in Ireland, the Higher Education Authority (HEA) indicates that today there are 24 higher education institutions, divided into 9 universities, 11 Institutes of Technology, and 4 institutions considered as "other colleges". Thus, according to White (2001), the increase in students from the 1960s to the present has been one of the most relevant phenomena. O'Connor and White (2011) consider that some of Ireland's universities have achieved good status internationally.

Parallel to this, brands have evolved over time to become a life experience for consumers, having acquired emotional importance that is reflected in the satisfaction of the people who buy and consume it (Camacho, 2008). Everything builds or destroys a brand, and this continuous and indefinite process over time must feed on all the actions that the company (or educational institution) directs to its public, as well as the interactions and experiences of the public with it (Olins, 2008). Thus, and taking into account that the market is increasingly complex and competitive, every educational center must aim at generating marketing and brand strategy adapted to the new consumer reality (Llorente, 2019). Within this process, 
the student becomes a key piece within the system, as in many cases they are considered clients (Sarrias, 2018). And, applying branding to the higher education sector, the student has a high impact on the university brand capital maximization process (Casanoves, Küster, and Vila, 2017).

In this framework, the objectives of the present research were to (1) establish which are the most determinant variables of brand capital in the higher education sector, and (2) decipher which are the most outstanding variables by university students in Ireland. Thus, and after reviewing the seven major proposals on brand capital models in the literature (Farquhar, 1989; Aaker, 1992; Keller, 1993; Faircloth, Capella, and Alford, 2001; Yoo and Donthu, 2001; Delgado and Munuera, 2002; Buil, Martínez and De Chernatony, 2010), we have considered four elements that are identified by these authors and were also deemed to be of importance in previous studies. These are: (1) brand awareness, (2) brand image, (3) perceived quality, and (4) brand loyalty.

To sum up, the realization of the present research supposes a scientific advance in the discipline of marketing; although there has been specific research into brand capital and the variables that compose it (Colmenares and Saavedra, 2007), it is considered that research does not presently exist that thoroughly analyses the perception of brand capital through the opinions of university students in Ireland. It can also help university managers because based on the results obtained on the significance of each of the variables of the educational brand capital and they can generate appropriate strategies to maintain or improve it.

\section{The perception of brand capital among public university students in Ireland}

After reviewing the seven main proposals on brand capital models made by the literature, four elements have been considered that shared by the authors, and taking into account the importance given in previous studies, we understand that their contribution to brand capital is key. These are: (1) brand awareness, (2) brand image, (3) perceived quality, and (4) brand loyalty. Each one of them is detailed below.

\subsection{Brand awareness}

In the specific field of education, several authors (Toma, Dubrow, and Hartley, 2005; Brewer and Zhao, 2010; Pinar, Trapp, Girard, and Boyt, 2014) find that branding in higher education is a very important variable for universities, in order to generate greater preference for consumption in educational services and, therefore, increase sales. In other words, greater brand awareness will mean greater brand equity. In view of the above, it is possible to raise the first research hypothesis: H1. The perception of brand awareness influences the perception of brand capital among Irish public university students.

\subsection{Brand image}

In the specific field of education, several authors (Hamann, Williams and Omar, 2007; Waeraas and Solbakk, 2009; Guzmán, Abimbola, and Whisman, 2009) have shown that the image of the brand in public and private universities is a very valuable asset for organizations, and effective and rapid measurements of the image transmitted to target audiences must be carried out since this perception may be different in both areas. This image, as it improves, will lead to increases in the brand capital of the university institution whose image is favored. In view of the above, it is possible to raise the second research hypothesis: $\mathrm{H} 2$. The perception of brand image influences the perception of brand capital among Irish public university students.

\subsection{Perceived quality}

In the specific field of education, several studies (Peltier, Schibrowsky, and Drago, 2007; Chen, 2008; Pinar, Trapp, Girard, and Boyt, 2014) show that the quality perceived in private and public higher education is a variable that also depends on the fact that it is up to educational institutions to obtain greater satisfaction from their users. Quality, therefore, is another key source in the configuration of the brand capital of the university institution, insofar as higher perceived quality will translate into greater brand capital. In view of the above, it is possible to raise the third research hypothesis: H3. The perception of perceived quality influences the perception of brand capital among Irish public university students.

\subsection{Brand loyalty}

In the specific field of education, several papers (Brown and Mazzarol, 2009; Paswan and Ganesh, 2009; Rojas, Vasquez, Kara and Cerdá, 2009) highlight the relevance of brand loyalty in the higher education sector, which implies that this variable is very important in generating educational brand capital. Audiences that are more loyal contribute to increasing brand equity. In view of the above, it is 
possible to raise the fourth research hypothesis: H4. The perception of brand loyalty influences the perception of brand capital among Irish public university students.

In view of the above, Figure 1 shows our proposed theoretical model designed to defend the present investigation.

Figure 1. Theoretical model proposed for the present research.

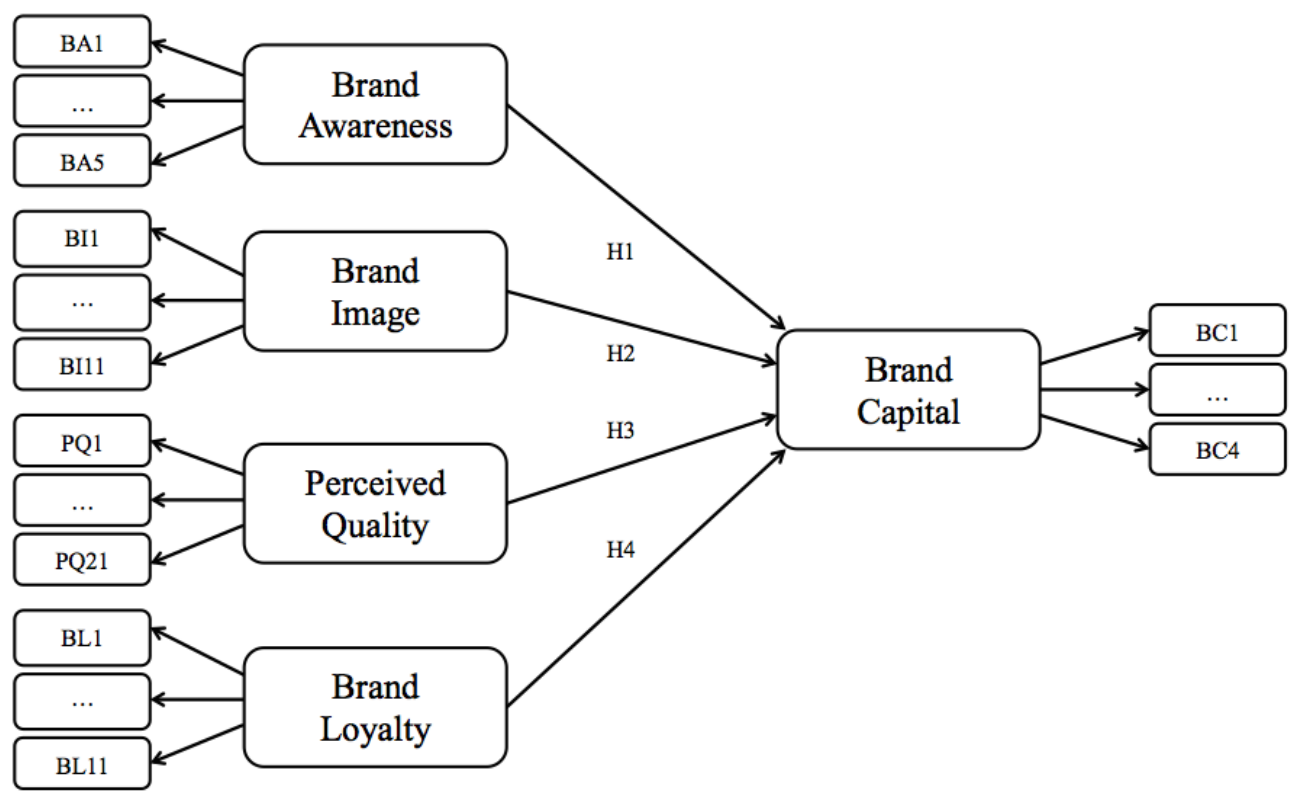

\section{Methodology}

In order to corroborate the established hypothesis, we conducted empirical research quantitative in nature, by means of a survey in the English language aimed at a group of 423 students from the two main public universities in Cork (Ireland).

Grade 5 Likert scales were used to measure the concepts of (1) brand awareness, (2) brand image, (3) perceived quality, and (4) brand loyalty. These scales are based on the measurement scales proposed by Aaker (1992) and Keller (1993) and were adapted to our field of study, higher education. The techniques for data analysis were based on descriptive statistics and multivariate analysis, using as a working tool SPSS v19 for Windows for descriptive techniques of data and SmartPLS 2.0 for executing multivariate techniques.

\section{Conclusions}

As a work in progress, it should be noted that we are currently in the analysis phase, through the application of different methods of analysis depending on the information to be obtained, distinguishing between (1) psychometric characteristics of the measuring instrument, divided into an analysis of the quality of the items and the validation of the scales; and (2) hypothesis testing, using a Structural Equations Modeling (EQS).

Once we finish this, we will document the conclusions and business implications for each variable proposed for our brand capital construct (brand awareness, brand image, perceived quality, and brand loyalty). With this, we will discuss the limitations of our research as well as future research, in order to open a new way for the scientific community.

\section{Acknowledgments}

This work was made possible by funding from Munster Technological University (Ireland).

\section{References}

Aaker, D. A. (1992). The value of brand equity. Journal of business strategy, Vol. 13(4), pp. 27-32.

Aldás, J. (2013). Partial least squares path modelling in marketing and management research: An annotated application. In Quantitative modelling in marketing and management (pp. 43-78). 
Batra, R., Ahuvia, A., \& Bagozzi, R. P. (2012). Brand love. Journal of marketing, 76(2), 1-16.

Brewer, A., \& Zhao, J. (2010). The impact of a pathway college on reputation and brand awareness for its affiliated university in Sydney. International Journal of Educational Management.

Buil, I., Martínez, E., \& De Chernatony, L. (2010). Medición del valor de marca desde un enfoque formativo. Cuadernos de gestión, 10, 167-196.

Camacho, J. (2008). El valor de la marca; Brand Equity. Página electrónica de Nielsen México. [en línea] Disponible en: http://mx. nielsen. com/press/Elvalordelamarca BrandEquity. shtml (consulta: diciembre de 2009).

Casanoves, J., Küster, I., \& Vila, N. (2017). Student loyalty as a key variable to build university brand capital. ESIC Market. Economic \& Business Journal, 48(3).

Chen, L. H. (2008). Internationalization or international marketing? Two frameworks for understanding international students' choice of Canadian universities. Journal of Marketing for Higher Education, 18(1), 1-33.

Colmenares, O. A., \& Saavedra, J. L. (2007). Aproximación teórica de la lealtad de marca: enfoques y valoraciones.

Delgado, E., \& Munuera, J. L. M. (2002). Medición del capital de marca con indicadores formativos. Investigación y marketing, (75), 16-20.

Durán, S., \& Parra, M. (2014). Diversidad Cultural para promover el desarrollo de habilidades sociales en educación superior. Revista Cultura, Educación y Sociedad, 5(1), 55-67.

Faircloth, J. B., Capella, L. M., \& Alford, B. L. (2001). The effect of brand attitude and brand image on brand equity. Journal of Marketing Theory and Practice, 9(3), 61-75.

Farquhar, P. H. (1989). Managing brand equity. Marketing research, 1(3).

García, J., \& Pelekais, C. (2012). La Dirección estratégica como factor potenciador de la Gestión del Conocimiento en Universidades Privadas: una perspectiva desde los Centros de Investigación. Material mimeografiado Jornadas del Centro de Investigación de Ciencias Administrativas y Gerenciales. CICAG. Universidad Dr. Rafael Belloso Chacín.

Guzmán, F., Abimbola, T., \& Whisman, R. (2009). Internal branding: a university's most valuable intangible asset. Journal of Product \& Brand Management.

Hamann, D., Williams, R. L., \& Omar, M. (2007). Branding strategy and consumer high-technology product. Journal of Product \& Brand Management.

Henao, L., \& Colorado, L. (2017). Calidad de servicio, satisfacción y antecedentes de la lealtad hacia las empresas de telecomunicaciones en Colombia. XXII Congreso Internacional de Contaduría, Administración e Informática. Ciudad Universidad. Ciudad Méjico.

Kaynak, E., Salman, G. G., \& Tatoglu, E. (2008). An integrative framework linking brand associations and brand loyalty in professional sports. Journal of Brand Management, 15(5), 336-357.

Keller, K. L. (1993). Conceptualizing, measuring, and managing customer-based brand equity. Journal of marketing, 57(1), 1-22.

Llorente, C. (2019). Marketing educativo: Captación y fidelización de alumnos. ESIC Editorial.

Manes, J. M. (2005). Marketing para Instituciones Educativas. Buenos Aires: Ediciones Granica S.A.

Morín, E. (2018). De la reforma universitaria.

O’Connor, P., \& White, K. (2011). Similarities and differences in collegiality/managerialism in Irish and Australian universities. Gender and education, 23(7), 903-919.

Olins, W. (2008). The brand handbook. Thames \& Hudson.

Paswan, A. K., \& Ganesh, G. (2009). Higher education institutions: Satisfaction and loyalty among international students. Journal of Marketing for Higher Education, 19(1), 65-84.

Peltier, J. W., Schibrowsky, J. A., \& Drago, W. (2007). The interdependence of the factors influencing the perceived quality of the online learning experience: A causal model. Journal of Marketing Education, 29(2), 140-153.

Pinar, M., Trapp, P., Girard, T., \& Boyt, T. E. (2014). University brand equity: an empirical investigation of its dimensions. International Journal of Educational Management.

Sarrias (2018). School marketing: como vender más siendo un centro de enseñanza. Profit Editorial.

Toma, J. D., Dubrow, G., \& Hartley, M. (2005). The Uses of Institutional Culture: Strengthening Identification and Building Brand Equity in Higher Education. ASHE Higher Education Report, Volume 31, Number 2. ASHE Higher Education Report, 31(2), 1-105.

Wæraas, A., \& Solbakk, M. N. (2009). Defining the essence of a university: Lessons from higher education branding. Higher education, 57(4), 449.

White, T. (2001). Investing in people: Higher education in Ireland from 1960 to 2000. Institute of Public Administration.

Yoo, B., \& Donthu, N. (2001). Developing and validating a multidimensional consumer-based brand equity scale. Journal of business research, 52(1), 1-14. 